\title{
sciendo
}

\section{INCUBATION BEHAVIOUR OF COMMON EIDERS Somateria mollissima IN THe Central Baltic: Nest atTendanCE AND loss in Body Mass}

\section{Valilno vedenje gag Somateria mollissima v Osrednjem Baltiku: prisotnost na gnezdu in izguba telesne mase}

\author{
Svend-Erik Garbus ${ }^{1,2}$, Peter Lyngs ${ }^{3}$, Mathias Garbus ${ }^{4}$, Pelle Garbus 5 , Igor Eulaers ${ }^{1}$, Anders Mosbech ${ }^{1}$, \\ Rune Dietz ${ }^{1}$, H. Grant Gilchrist ${ }^{6}$, Rene Huusmann ${ }^{2}$, Jens Peter Christensen ${ }^{2}$, Christian Sonne ${ }^{*}$
}

1 Aarhus University, Department of Bioscience, Arctic Research Centre (ARC), Frederiksborgvej 399, PO Box 358, DK-4000 Roskilde, Denmark (SE Garbus: se.garbus@gmail.com; C Sonne: cs@bios.au.dk; I Eulaers: ie@ bios.au.dk; A Mosbech:amo@bios.au.dk; RDietz: rdi@bios.au.dk)

2 University of Copenhagen, Faculty of Health and Medical Sciences, Department of Veterinary Disease Biology, DK-1870 Frederiksberg, Denmark (JP Christensen: jpch@sund.ku.dk; R Huusmann: tgc720@alumni.ku.dk)

3 Christiansø Scientific Field Station, Christiansø 97, DK-3760 Gudhjem, Denmark (pl.lynx@gmail.com)

4 Daddellunden 14, DK-8960 Randers SØ, Denmark (m@garbus.dk)

5 Aarhus University, Department of Chemistry and iNANO, Center for Materials Crystallography, Langelandsgade 140, DK-8000 Aarhus C, Denmark (P Garbus: garbus@inano.au.dk)

6 National Wildlife Research Centre, Environment Canada, Raven Road, Carleton University, Ottawa, Ontario K1A 0H3, Canada (Grant.Gilchrist@ec.gc.ca)

Corresponding author: Professor Christian Sonne, DScVetMed, PhD, DVM, Dipl. ECZM (Wildlife Health), Aarhus University, Faculty of Science and Technology, Department of Bioscience, Frederiksborgvej 399, PO Box 358, DK4000 Roskilde, Denmark. Tel. +45-30-78-31-72; fax: +45-87-15-50-15; Email address: cs@bios.au.dk (C. Sonne).

Here we present the recording of body mass change and weight loss during incubation in a Common Eider Somateria mollissima colony at Christiansø in the Central Baltic $\left(55^{\circ} 19^{\prime} \mathrm{N} 15^{\circ} 11^{\prime} \mathrm{E}\right)$. The study was conducted during April and May 2015 and a total number of four birds were followed (two were lost due to predation and three due to power outages). Body mass and nesting behaviour was recorded electronically over a period of 26-27 days using automatic poultry scales and a surveillance video camera. During incubation, the eiders underwent a $28-37 \%$ loss in body mass and left the nest on average 13 times (range: 7-17 times) for a period of 7-70 min. In general, birds with high initial body mass left their nest for a shorter total time than birds with lower initial body mass. The recorded daily changes in body mass indicate that the eiders foraged during the incubation period, not just leaving the nest for rehydration or in response to disturbance, which improve our current understanding of eider incubation behaviour. Such information is important to fully understanding of eider breeding biology in order to better conserve and manage the species during its breeding seasons where individual birds undergo extreme stress that may affect reproductive outcome and adult survival.

Keywords: camera, nest, hydrating, feeding, foraging, recess behaviour Ključne besede: kamera, gnezdo, hidracija, prehranjevanje, iskanje hrane, vedenje med odsotnostjo z gnezda 
S-E. GARBUs et al: Incubation behaviour of Common Eiders Somateria mollissima in the Central Baltic: Nest attendance and loss in body mass

\section{Introduction}

Common Eiders Somateria molissima are colonial breeders with females exhibiting a high degree of philopatry (CHOATE 1966, Clark 1968, Milne 1974, WAKELEY \& MENDALl 1976). Initially, the male accompanies the female, defending its mate for fertilization assurance, but as incubation progresses the male loses interest in the female (BLUMPTON et al. 1988, Hario \& Holmén 2004, Milne 1974). Eider clutches average 4 to 5 eggs in Danish and Finnish eider colonies and the eggs hatch after approx. 26 days of incubation (BREGNBALLE 2002, Goudie et al. 2000, Hario \& SELIN 1987).

During incubation, body reserves from wintering grounds are crucial for the reproduction of eiders (LAURSEN et al. 2018, 2019). As the sole incubator in the nesting process, the female eider relies primarily on these accumulated reserves. Prior to incubation, the process of egg development facilitates the mobilization of minerals and nutrients (AlONSO-AlvAREZ et al. 2002, Wilcox 1965), which affect general health, physiology and biochemistry (GARBUS 2016).

During incubation, the female rarely leaves the nest unless disturbed, for occasional preening or bathing or in need of rehydration (MCARTHUR \& GoRMAN 1978, SwENNEN et al. 1993, Bolduc \& GuillemetTe 2003). The female relies on nutrient reserves and especially fat reserves and pectoral muscles are metabolised (Korschgen 1976, Milne 1976, Parker \& Holm 1990). Studies have shown incubation intermissions to last for 4-17 min primarily during the night (BoLduC \& Guillemette 2003, Bотtitta et al. 2003, CRIsCuOlo et al. 2000, SwENNEN et al. 1993).

The incubation period is energy-demanding and females lose 23-46\% of their pre-laying body mass. A proportion of the incubating females may not have sufficient nutrient reserves to complete the incubation period and, consequently, clutches of eggs are occasionally abandoned (FRANZMANN 1980, Gabrielsen et al. 1991, HaRĐardótTIR et al. 1997, MaWhinney 1999, Parker \& Holm 1990). During incubation, typically three metabolic stages exist, each addressing different types of energy. Throughout stage I, protein catabolism decreases and fat metabolism increases. During stage II, the energy utilized is primarily fat. In stage III protein catabolism increases again. In fact, these latter biochemical changes allowed a Finnish study on incubating eiders in 1997-199 to pinpoint specific years in which stage III was reached (Hollmén et al. 2001) which was shown again in the Christiansø eider colony by Garbus (2016) in 2015. The mobilization of lipids and nutritional reserves releases persistent organic pollutants and heavy metals to the blood, which together with nutrient-deficiency lead to immune suppression and affect the breeding success (Hollmén et al. 2001, HANSSEN et al. 2003, MALlory et al. 2004, BALDASSARRE 2014). Furthermore, body mass or body condition may also affect brood care behaviour long after hatching, affecting survival of ducklings as well (Öst et al. 2003).

It is important to develop minimally invasive tools that allows us assessing the general health of eiders during the incubation period. Here we present data on body mass changes and nest attendance behaviour of the common eider using electronic scales and video surveillance. This allow us to further study behaviour and stress that incubating eiders undergo during the breeding season and determine the most important factors for breeding success. The study was conducted in a colony in the Central Baltic Sea. Here the eiders are migrants, returning to the colony in late February and conduct their main 26-day incubation from mid-April to mid-May. The very last eggs usually hatch in early June (FranzmanN 1980, LyngS 1992).

\section{Materials and methods}

\subsection{Study design}

The study colony is located on Christiansø which is part of the Ertholmene archipelago northeast of Bornholm in the Central Baltic Sea $\left(55^{\circ} 19^{\prime} \mathrm{N}\right.$ $15^{\circ} 11^{\prime} \mathrm{E}$, DK-3760 Gudhjem) (Figure 1). Each year, ca. 1500 eiders breed at Ertholmene (LYNGS 2014). In April 2015, a study plot of app. $900 \mathrm{~m}^{2}$ was checked daily (09.00-10.00 am) to locate potential nests for scale monitoring and camera surveillance. New nests with 1-2 pre-incubated eggs were marked with ID-number and GPS position. A thin spike was used to check if the layer of soil was sufficiently thick for placing the scale measuring 


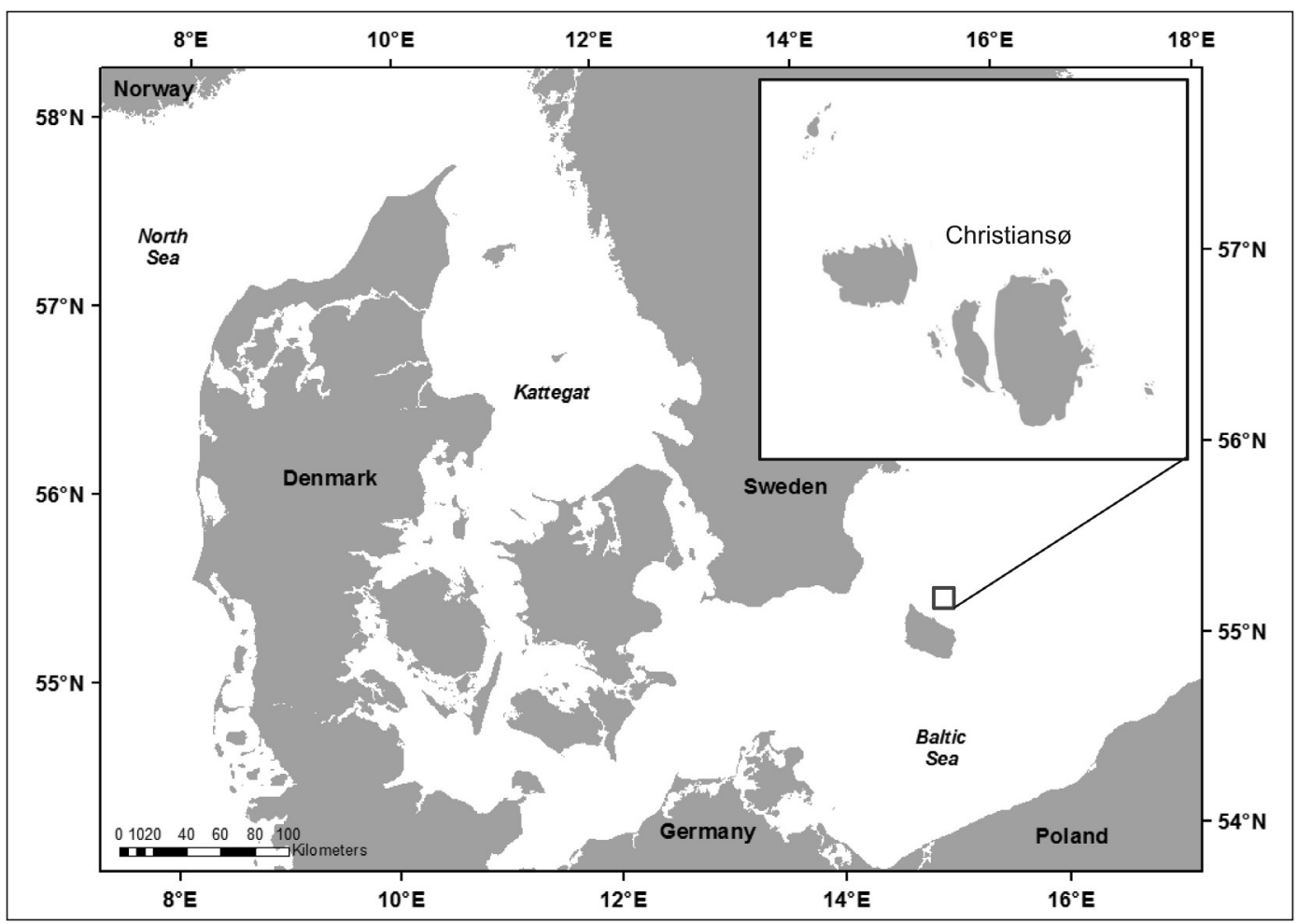

Figure 1: Map of the study area.

Slika 1: Zemljevid obravnavanega območja

$22 \mathrm{~cm} \times 7 \mathrm{~cm}(\mathrm{w} \times \mathrm{h})$. Then, eggs and nest material were temporarily removed and the soil excavated to make space for the scales. In addition, plastic saucers were used to separate the scales from the ground and the nest material. After deployment, the modified nests and their content were placed to the exact same level compared to the surrounding area as before (Figure S1). One camouflaged camera was installed within $1 \mathrm{~m}$ of one of the nests installed with scale system (Figure S2). Recording of data started hereafter.

\subsection{Automatic scale and camera surveillance}

We placed an automatic poultry scale system based on the scales DOL 94-10 from SKOV A/S (Glyngøre 7870 Roslev, Denmark http://skov.com) in nine eider nests. Two nests were predated by Herring Gulls Larus argentatus, and in three nests data was lost due to power outages. Consequently, datasets were obtained from four nests that all hatched successfully. Scales were connected with a cable to a panel box and the surveillance camera was connected via network cable to a router hidden in a plastic container in the nesting area. Scales were finally connected to a modified Raspberry Pie Microcomputer (RPM), which collected and stored raw signals in a database by using an Analogue to Digital Converter (ADC). The measuring error due to the resolution of the scales and 18 bit $\mathrm{ADC}$ was $\pm 10.6 \mathrm{~g}$. This was considered more than sufficient since other disturbances like rain, wind, temperature, unstable power, dirt and movements of the bird affect the measurements with similar or larger perturbations. The RPM was programmed to acquire raw mass data and time every $5 \mathrm{sec}$. This information was stored in a database.

We mounted a Foscam FI9805 HD $4 \mathrm{~mm}$ PoE surveillance camera near one nest site in the period April-June 2015. The Foscam Network 
S-E. GARBUs et al: Incubation behaviour of Common Eiders Somateria mollissima in the Central Baltic: Nest attendance and loss in body mass

Video Recorder FN3104H camera was supplied by ShenZhen Intelligent Technology Cooperation. The camera recorded 10 frames per $s$ and data was automatically stored on an external server. Recording during dark hours was made possible due to the cameras' build-in infrared light technology. Microsoft Movie editor (Microsoft Inc. 2015) was used to edit the recordings. In this study, the scales and surveillance camera were placed without disturbance as the placements were carried out during the pre-incubation period.

\subsection{Body mass data}

In order to increase the limited sample size of this present study, we also included data reported by Bolduc \& GuillemetTe (2003) to see whether their results were different from those of this present study. The absolute recorded mass could not be used directly to determine the body mass of the bird. Instead, we used the recorded mass right before departure subtracting the mass of the nest content.
This mass difference $(\Delta \mathrm{W})$ was extracted for all incubation intermissions for every bird (Figure 2).

\subsection{Statistical analyses and graphical presentations}

All basic statistics were performed using R ( $R$ CORE TEAM 2018). Due to low sample size, only visual graphical interpretations were used. A moving average was applied to the graphical presentation of the mass development to smooth out short-term fluctuations.

\section{Results and Discussion}

\subsection{Incubation intermissions and nest-leave behaviour}

On average, the incubating eiders left their nests 13 times (range: 7-17 times; Table 1) during the 26-day incubation period. Each leave lasted for $34 \mathrm{~min}$ on average (range: 7-70 min; Table 1).

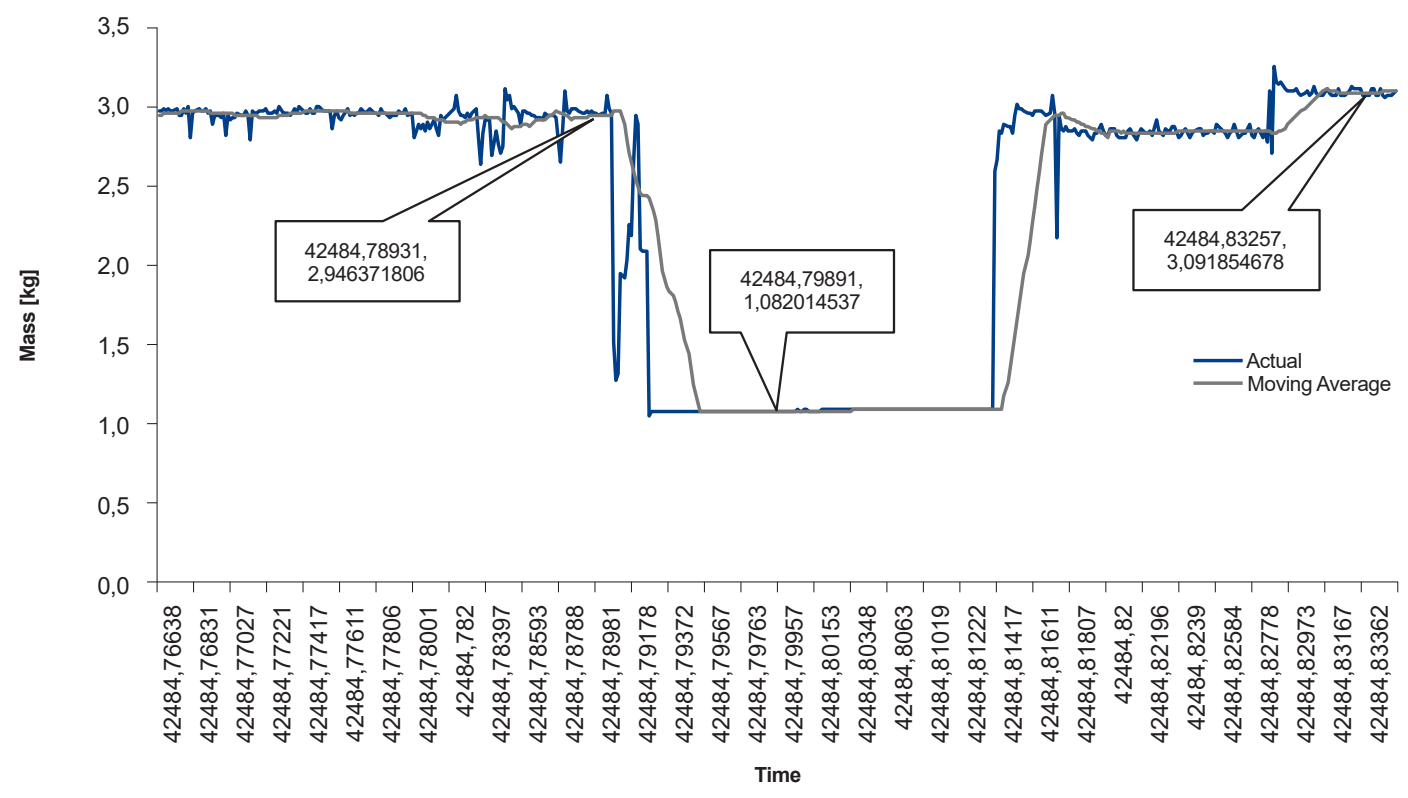

Figure 2: Data collected from one of the automatic poultry scales and illustrated graphically providing information of the mass of the nest and the incubating female. The flat part of the curve illustrates an incubation intermission.

Slika 2: Podatki ene od avtomatskih tehtnic, ki so beležile maso valeče samice. Ravni del krivulje predstavlja premor med valjenjem 
Table 1: Basic incubation data of Christiansø Common Eiders Somateria mollissima

Tabela 1: Osnovi podatki o valjenju gag Somateria mollissima v arhipelagu Christians $\varnothing$

\begin{tabular}{|c|c|c|c|c|c|c|c|c|}
\hline \multirow[b]{2}{*}{ ID } & \multicolumn{2}{|c|}{ Incubation / Valjenje } & \multicolumn{2}{|c|}{$\begin{array}{r}\text { Time away from nest } \\
\text { / Čas z gnezda }\end{array}$} & \multirow[b]{2}{*}{$\begin{array}{r}\text { Time } \\
\text { on nest } \\
\text { / Čas na } \\
\text { gnezdu } \\
\text { (d) }\end{array}$} & \multirow[b]{2}{*}{$\begin{array}{r}\text { Rate } \\
\left(\mathrm{g} \mathrm{d}^{-1}\right)\end{array}$} & \multirow[b]{2}{*}{ Absolute (g) } & \multirow{2}{*}{$\begin{array}{r}\text { Mass loss } \\
\text { Relative } \\
(\%) \\
\end{array}$} \\
\hline & $\begin{array}{r}\text { Time } \\
/ \text { Čas } \\
\text { (d) }\end{array}$ & $\begin{array}{r}\text { Intermissions / } \\
\text { Premori }\end{array}$ & $\begin{array}{r}\text { Total / } \\
\text { Skupno } \\
\text { (min) }\end{array}$ & $\begin{array}{r}\text { Per trip / } \\
\text { Posamezen } \\
\text { odhod } \\
(\text { min })\end{array}$ & & & & \\
\hline$\# 01$ & 27 & 7 & 188 & $27(7-43)$ & $4(2-7)$ & 26 & $\begin{array}{r}692 \\
(2248-1556)\end{array}$ & 31 \\
\hline \#02 & 26 & 17 & 534 & $31(12-63)$ & $2(1-5)$ & 20 & $\begin{array}{r}529 \\
(1884-1355)\end{array}$ & 28 \\
\hline \#03 & 26 & 10 & 521 & $52(35-70)$ & $2(1-5)$ & 27 & $\begin{array}{r}707 \\
(1911-1204)\end{array}$ & 36 \\
\hline \#04 & 26 & 16 & 442 & $28(11-51)$ & $2(1-3)$ & 25 & $\begin{array}{r}655 \\
(1761-1106)\end{array}$ & 37 \\
\hline $\begin{array}{l}\text { Average / } \\
\text { Povprečje }\end{array}$ & 26 & 13 & 421 & 34 & $3(1-5)$ & 25 & 646 & 33 \\
\hline
\end{tabular}

Table 2: Observed mass changes after incubation intermission of the Christiansø Common Eiders Somateria mollissima compared to the Saltholm study (BOLDuc \& GUILLEMETTE 2003).

Tabela 2: Opazovane spremembe mase gag Somateria mollissima med premori v valjenju - primerjava te raziskave z raziskavo na otoku Saltholm (Bolduc \& GUILLEMETTE 2003).

\begin{tabular}{rrrrrr}
\hline $\begin{array}{c}\text { Intermissions / } \\
\text { Premori }\end{array}$ & Gain (g) & Loss $(\mathrm{g})$ & No gain $/$ loss & Gain $(\mathrm{g})$ & Mass/Masa \\
\hline & $18(36 \%)$ & $25(50 \%)$ & $7(14 \%)$ & $49 \pm 21(16-88)$ & $44 \pm 22(11-89)$ \\
$\mathrm{n}=50$ & $12(16 \%)$ & $51(67 \%)$ & $13(17 \%)$ & $117 \pm 75$ & \\
$\mathrm{n}=76$ & & &
\end{tabular}

This is slightly longer compared to previous studies from the Danish island Saltholm showing that the number of incubation intermissions was on average 12 times (range: 9-19 times; Table 2) and lasting for on average $14 \mathrm{~min}$ (range: 3-42 min; Table 2, see below for details) (Bolduc \& GUILlEMETTE 2003). The reasons for this is unknown but could be due to differences in body condition, food access and presence of predators.

The birds left on average every second day and the interval between each incubation intermissions varied 1-7 days. As suggested from Figure S3-6, the time elapse between incubation intermissions (days) did not change from the beginning to the end of incubation while the length of intermissions ( $\mathrm{min}$ ) seem to decrease slightly. This, however, based on a few individuals and a larger sample is required for statistical tests. Incubation intermissions mostly took place around the same time of the day, i.e. after sunset between 21:00-24:00 (Figure S3-6). Out of 50 incubation intermissions only $3(6 \%)$ were found to occur during daylight and all by the same bird (\#04; Figure S6). The investigations on Saltholm by Bolduc \& GuillemetTe (2003) showed a slightly higher daytime occurrence with eight of 61 intermissions (13\%). For every 
S-E. GARBUs et al: Incubation behaviour of Common Eiders Somateria mollissima in the Central Baltic: Nest attendance and loss in body mass

intermission, the birds carefully covered up their eggs with down (Figure S7). According to the webcam, this took approx. $60 \mathrm{~s}$. While the female was absent, the eggs were thus protected by both dusk and down. The eiders left their nest for a total time of $421 \mathrm{~min}$ (range: $188-534 \mathrm{~min}$; Table 1). In comparison, the Saltholm study (BolduC \& GuILLEMETTE 2003) showed that the birds left their nest for $190 \mathrm{~min}$ (range: $101-270 \mathrm{~min}$ ). This suggests that the Saltholm population may have had a better body condition, better food access or was more affected by predators. The incubating eiders lost 33\% (range: 28-37\%) of their initial body mass on average. Other investigations have shown a mass loss of 23-46\% (Bolduc \& GUillemetTe 2003, Franzmann 1980, Gabrielsen et al. 1991, HarĐardótTir et al. 1997, Korschgen 1976, PARKer \& Holm 1990). The incubating eiders lost on average $646 \mathrm{~g}$ (range: $529-707 \mathrm{~g}$ ). The loss of body mass was $25 \mathrm{~g} \mathrm{~d}^{-1}$ (range: $20-27 \mathrm{~g} \mathrm{~d}^{-1}$ ) on average. In comparison, the Saltholm study showed an average body mass loss of $975 \mathrm{~g}$ (range: 723-1126 g), a mass loss rate of $37.5 \mathrm{~g} \mathrm{~d}^{-1}$ and a relative mass loss of $42 \%$ likely due to a higher initial body condition. Other studies of nesting eiders have shown body mass loss of 15-30 $\mathrm{g} \mathrm{d}^{-1}$ (Bolduc \& GuillemetTe 2003, Criscuolo et al. 2002, Erikstad \& TveraA 1995, FranzMANN 1980, GABRIELSEN et al. 1991, HARĐARDótTir et al. 1997, KorsCHGEN 1976, LAUrila \& Hario 1998, PARKer \& Holm 1990).

\subsection{Changes in body mass}

The distance to the sea from the study plot was $100-130 \mathrm{~m}$. Due to an average incubation intermission of 34 min compared to the short distance to the sea it would be possible for the bird to allocate time for both rehydrating and foraging. Of 50 incubation intermissions recorded (Table S1-4), 18 were associated with mass gain, on average $48 \mathrm{~g}$ (range: $16-88 \mathrm{~g}$ ), 25 with mass loss, on average 43 g (range: 11-89 g; Table 2), and seven were outside the confidence of measuring due to measuring error of \pm 10.6 (Materials and methods). The 18 intermissions associated with mass gain lasted on average 39 min (range: 11-70 $\mathrm{min}$ ) while the average incubation intermission was at $34 \mathrm{~min}$.

Although there has been consensus that nesting eiders do not feed during the incubation period
(Korschgen 1976, Milne 1976, Parker \& Holm 1990) it has recently been suggested that they may do so nevertheless (Bolduc \& Guillemette 2003, Criscuolo et al. 2002). Numerous dives (Criscuolo et al. 2002), unusually long at times, and necks distended on the way back to the nest (BOLDUC \& GUILLEMETTE 2003) could be signs of food ingestion. At Christiansø, similar observations were reported. At a mass mortality event in 2007 caused by starvation small piles of 5-14 mm regorged blue mussels (Mytilus edulis) were found in close vicinity of seven incubating eiders (LYNGS 2007, GARBUS et al. 2018), indicating foraging.

\subsection{Intermissions and body mass}

Blue mussels are the principal food item for eiders (Hario \& Öst 2002, Hilgerloh 1999, Madsen 1954, Nehls 2002, Swennen 1976). The quality of mussels may affect both the time foraging and the amount of ingested food. If so, this may indicate that the blue mussel beds around Christiansø may be of poor condition. Earlier studies have suggested occasional poor health of blue mussels in the Baltic sea caused by Prymnesium polylepsis blooms (LARsSON et al. 2014), which may be lethal to this species (JoHn et al. 2002, NiELSEN et al. 1990, SCHMidT \& HANSEN 2001, Underdahl et al. 1989).

The incubation intermissions could be to rehydrate as well as forage. However, since the daily diving time usually required to maintain energy balance in this species is $140 \mathrm{~min}$, the ingestion of prey is probably lower than outside incubation (Guillemette 1998). Bolduc \& Guillemette (2003) found an average mass gain of $117 \mathrm{~g}$ in the Saltholm colony, when mass gains were observed under the incubation intermissions, which is higher than the present study. Altogether, the present and Bolduc \& GuillemetTe (2003) studies suggest that incubating eiders with a lower mass at the onset of the incubation period may spend in total more time away from the nest than eiders with a higher initial mass. If that is true, incubating eiders with sufficient reserves will reduce their time away from the nest to avoid nest predation or risk of poor egg development (GARBus et al. In press). Studies on other incubating waterfowl indeed support our observations on incubating behavior in relation to 
initial body mass (Afton \& PAulus 1992, AlRich \& Raveling 1983, Yerkes 1998) but more data is required to investigate this further.

\subsection{Scale and camera}

Regarding the eiders nesting behaviour, only data for the eider \#02 was presented for illustration of our methods (Figure 3). Figures for the remaining eiders are found in Figure S8-11. Movements of the incubating eiders on the nests were reflected as semi-long spikes (green arrows) in a diurnal pattern. The spikes were due to activities such as standing up, turning the eggs and preening in the nest. Hatching of the chicks was reflected as extra closely placed spikes (red arrows) on the graphs at the end of the incubation period. Selected points on the graph of \#01 (Figure S8) were compared to the recorded video material (S12). The scale and camera instruments employed in the present study showed to be very effective in accurately measuring the timing of incubation intermissions as well as associated mass changes. As such, it can potentially elucidate how individual stress during the incubation period may ultimately result in dramatic population effects, as has been recorded for the Baltic population (Ekroos et al. 2012, Skov et al. 2011).

\section{Conclusion}

During incubation, the Christiansø eiders underwent a $28-37 \%$ loss in body mass and left the nest on average 13 times (range: 7-17 times) for a period of 7-70 min. Birds with high initial body mass seem to leave their nest for a shorter total time than birds with lower initial body mass. Our results contribute to the further understanding of eider incubation behaviour to fully understanding their breeding biology in order to better conserve and manage the species during its breeding seasons where individual birds undergo extreme stress that may affect reproductive outcome and adult survival.

\section{Acknowledgements}

The study was approved by the Danish Nature Agency (SVANA). For Funding of the study, we acknowledge The Danish Environmental Protection Agency, 15. Juni Fonden, Jægernes Naturfond, SKOV A/S (Glyngøre 7870 Roslev, Denmark) and BONUS BALTHEALTH that has received funding from BONUS (Art. 185), funded jointly by the EU, Innovation Fund Denmark (grants 6180-00001B and 6180-00002B), Forschungszentrum Jülich $\mathrm{GmbH}$, German Federal Ministry of Education and Research (grant FKZ

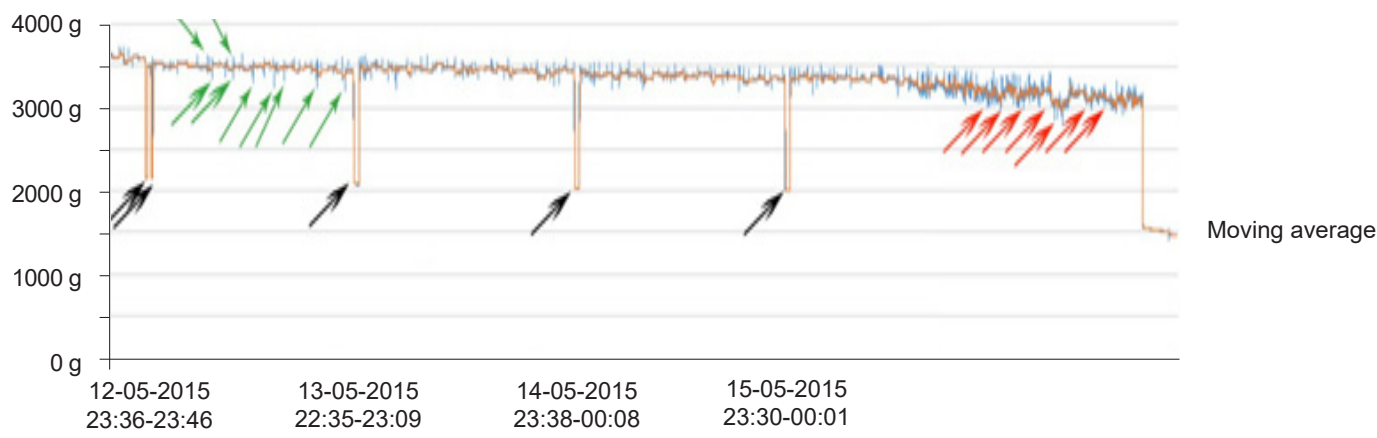

Figure 3. The last part of the 26-day incubation period of female \#02 constructed from the raw time-mass data. Note the spikes facing downwards, showing the bird leaving the nest (black arrows). The smaller spikes are due to activity of the bird in the nest (green arrows). Hatching of chicks are reflected as extra closely placed spikes on the graphs at the end of the nesting periods (red arrows).

Slika 3: Zaključni del 26-dnevnega valjenja samice \#02. Navzdol obrnjene konice (črne puščice) označujejo čas, ko je samica gnezdo zapustila, manjše konice označujejo aktivnost na gnezdu (zelene puščice), izvalitev mladičev pa rdeče puščice. 
S-E. GARBUs et al: Incubation behaviour of Common Eiders Somateria mollissima in the Central Baltic: Nest attendance and loss in body mass

03F0767A), Academy of Finland (grant 311966) and Swedish Foundation for Strategic Environmental Research (MISTRA). In addition, we are grateful to the people of Christiansø for their help. A permission regarding potential disturbance and the handling of eggs and nests material (license J.nr. NST-304-0008) was kindly granted by the Nature Agency. Power for the technical setup as well as an online connection was kindly provided by the local school (Christiansø 4, 3760 Gudhjem, Denmark). Finally, Tatiana Kaplun is acknowledged for editing.

\section{Povzetek}

Predstavljamo spremembe telesne mase pri gagah Somateria mollissima med valjenjem na koloniji na otočju Christiansø v osrednjem Baltiku (5519'N $\left.15^{\circ} 11^{\prime} \mathrm{E}\right)$. Raziskava je potekala aprila in maja 2015 , spremljali smo štiri ptice (dve sta bili uplenjeni, pri treh manjkajo podatki zaradi težav z napajanjem). Telesno maso in gnezditveno vedenje smo 26-27 dni spremljali z avtomatsko perutninsko tehtnico in nadzorno kamero. Med valjenjem so gage izgubile 28-37 \% telesne mase in gnezdo zapustile v povprečju 13-krat (razpon: 7-17) za 7-70 minut. V splošnem so ptice $\mathrm{z}$ višjo izhodiščno maso gnezdo zapuščale za krajši čas kot ptice $\mathrm{z}$ nižjo maso. Meritve mase kažejo, da so se ptice med valjenjem tudi prehranjevale in gnezd niso zapuščale le zaradi pitja in motenj. Ta nova spoznanja so pomembna za razumevanje gnezditvene biologije gag in načrtovanje varstvenih ukrepov med gnezditveno sezono.

\section{References}

Afton A. D., Paulus S. L. (1992): Incubation and brood care. In: BATT B. D. J., AFTON A. D., ANDERSON M. G., ANKNEY C. D., JOHNSON D. H., KADLEC J. A., KRAPU G. L., eds. Ecology and management of breeding waterfowl. UMP. 3061.

Alonso-alvarez C., Velando A., Ferrer M., VEIRA J.A. (2002): Changes in plasma biochemistry and body mass during incubation in the yellowlegged gull. - Waterbirds. 25: 253-258.

Alrich T. E., Raveling D. G. (1983). Effects of experience and body weight on incubation behavior of Canada Geese. - Auk 100: 670-679.
Baldassarre G. A. (2014): Ducks, Geese and Swans of North America. - Johns Hopkins University Press, Baltimore, Maryland, USA.

Blumpton A. K., Owen R. B., Krohn W. B. (1988): Habitat suitability index models: American Eider (breeding). - U.S. Fish. Wildl. Serv. Biol. Rep. 82 (10.149).

Bolduc F., Guillemette M. (2003): Incubation constancy and mass loss in the Common eider Somateria mollissima. - Ibis. 145: 329-332.

Bottitta G. E., Noel E., Gilchrist H. G. (2003): Effects of experimental manipulation of incubation length on behaviour and body mass of Common eiders in the Canadian arctic. - Waterbirds. 26: 100-107.

Bregnballe T. (2002): Clutch size in six Danish sommon eider (Somateria mollissima) colonies: Variation in Egg Production. - Dan. Rev. Game Biol. 16: 7-14.

Choate J. S. (1966): The breeding biology of the American Eider in Penobscot Bay, Maine. - M.S. Thesis, Univ. of Maine, Orono. 173 pp.

Criscuolo F., Gabrielsen G. W., Gender J. P., Maho Y. L. (2002): Body mass regulation during incubation in female common eiders Somateria mollissima. - J. Avian Biol 33: 83-88.

Criscuolo F., Gauthier-clerc M., Gabrielsen G. W., Maho Y. L. (2000): Recess behavior of the incubating Common Eider Somateria mollissima. Polar Biol 23: 571-574.

Clark S. H. (1968): The breeding ecology and experimental management of the American Eider in Penobscot Bay, Maine. - M.S. Thesis, Univ. of Maine, Orono. 169 pp.

Ekroos J., Fox A. D., Christensen T. K, Petersen I. K., Kilpi M., Jonsson J. E., Green M.M, Laursen K., Cervencl A., DE boer P., Nilsson L., Meissner W., Garthe S., Öst M. (2012): Declines amongst breeding eider Somateria mollissima numbers in the Baltic/Wadden Sea Flyway. - Ornis Fenn 89: 81-90.

Erikstad K. E., Tveraa T. (1995): Does the cost of incubation set limits to clutch size in Common Eiders Somateria mollissima? Oecologia 103: 270-274.

Franzmann N. E. (1980): Ederfuglens (Somateria mollissima) ynglebiologi og populationsdynamik på Christiansø 1973-1977. - PhD dissertation, University of Copenhagen. (In Danish).

Gabrielsen G. W., Mehlum F., Karlsen H. K., Andersen O., Parker H. (1991): Energy cost during incubation and thermoregulation in the female Common Eider. (Somateria mollissima). Norsk Polarinst. Skr. 195: 51-62.

Garbus S. E. (2016): Health, behaviour, egg failure and starvation-mortality of incubating common eiders 
(Somateria mollissima) at Christiansø, Central Baltic Sea, 2015. - MSc thesis, University of Copenhagen, Denmark. 73 pp.

Garbus, S.E., Lyngs, P., Christensen, J.P., Buchmann, K., Eulaers, I., Mosbech, A., Dietz, R., Gilchrist, H.G., Sonne, C. (2018): Common eider (somateria mollissima) body condition and parasitic load during a mortality event in the Baltic proper. Avian Biol Res 11:167-172.

Garbus, S.E., Lyngs, P., Christensen, J.P., Sonne, C. (In press): Candling and field atlas of early egg development in common eiders (Somateria molissima). Acrocephalus 39 (178/179): 85-90.

Goudie, R. I., Robertson, G. J., A. Reed. (2000): Common Eider (Somateria mollissima). In The Birds of North America, No. 546 (A. POOLE, F. GILL eds.). The Birds of North America, Inc, Philadelphia, PA.

Guillemette, M. (1998): The effect of time and digestion constraints in Common Eiders while feeding and diving over Blue Mussel beds. Funct. Ecol. 12: 123-131.

Hanssen, S.A., Folstad, I., Erikstad, K.E. (2003). Reduced immunocompetence and cost of reproduction in common Eiders. Oecologia. 136: 457-464.

Hario, M., Selin, K. (1987): The variation in clutch size and egg volume in different age classes of the Common Eider. Suomen Riista. 34: 59-65. (English summary).

Hario, M., Hollmén, E.T. (2004): The role of male mate-guarding in pre-laying Common Eiders Somateria m. mollissima in the northern Baltic Sea. Ornis Fennica. 81: 119-127.

Hario, M., Öst, M. (2002): Does heavy investment in foraging implicate low food acquisition for female Common Eiders Somateria mollissima? Ornis Fenn. 79: 111-120.

HarĐardóttir, M., GuĐmundsson, J., Petersen, Æ. (1997): pyngdartap aeðarkolla Somateria mollissima á álegutíma. Bliki. 18: 59-64. (In Icelandic).

HilgerloH, G. (1999): Year to year changes in the share of cockles (Cerastoderme edule) and the blue mussels (Mytilus edulis) in the food of eiders (Somateria mollissima) on six East Frisian Islands. Senck. Marit. 29: 71-73.

Hollmén, T., Franson, J.C., Hario, M., Sankari, S., Kilpi, M., LindSTRÖM, K. (2001): Use of Serum Biochemistry to Evaluate Nutritional Status and Health of Incubating Common Eiders (Somateria mollissima) in Finland. Physiol Biochem Zool. 74: 333-342.

John, U., Tillmann, U., Medlin, L.K. (2002): A comparative approach to study inhibition of grazing and lipid composition of a toxic, non-toxic clone of
Chrysochromulina polylepsis (Prymnesiophyceae). Harmful Algae. 1: 45-57

Korschgen, C. E. (1976): Breeding stress of female eiders. Ph.D. dissertation, University of Maine, Orono. 110 pp.

Laursen, K., Møller, A.P., Haugaard, L., Öst, M., VAINIO, J. (2019): Allocation of body reserves during winter in eider Somateria mollissima as preparation for spring migration and reproduction. J Sea Res. 144: 49-56.

Laursen, K., Møller, A.P., Öst, M. (2018). Body condition of Eiders at Danish wintering grounds and at pre-breeding grounds in Åland. J Ornithol. 160: 239-248.

Larsson, K., Hajdu, S., Kilpi, M., Larsson, R., Leito, A., Lyngs, P. (2014): Effects of an extensive Prymnesium polylepsis bloom on breeding eiders in the Baltic Sea. J. Sea. 88: 21-28

Laurila, T., Hario, M. (1988): Environmental and genetic factors influencing clutch size, egg volume, date of laying and female weight in the common eider Somateria mollissima. FGFRI. 45: 19-30.

LYNGS, P. (1992): Ynglefuglene på Græsholm 1925-90. Dansk Orn. Foren. Tidsskr. 94: 12-18 (In Danish with an English summary).

Lyngs, P. (2007): Christiansø Fieldstation http://chnf. dk/aktuelt/edfugl07/edfugls07_2sp.php (accessed November 2015, in Danish).

Lyngs, P. (2014): Christiansø Fieldstation http:// www.chnf.dk/aktuelt/edf14/edfugl14.php (accessed November 2015, in Danish).

Madsen, F.J. (1954): On the food habits of the diving ducks in Denmark. Dan. Rev. Game Biol. 2: 157-266.

Mallory, M. L., Braune, B. M., Wayland, M., Gilchrist, H. G., Dickson, D. L. (2004): Contaminants in common eiders (Somateria mollissima) of the Canadian Arctic Environ Rev. 12: 197-218.

Mcarthur, P. D., Gorman, M. L. (1978): The salt gland of the incubating Eider duck Somateria mollissima: the effects of natural salt deprivation. J. Zoo. 184: 83-90.

Milne, H. (1974): Breeding numbers and reproductive rate of eiders in the sands of Forvie National Nature Reserve, Scotland. IBIS. 116: 135-152.

Milne, H. (1976): Body weights and carcass composition of the Common Eider. Wildfowl. 27: 115-122.

Nehls, G. (2002): Do common eiders Somateria mollissima exhaust their food resources? A study on natural mussel Mytilus edulis beds in the Wadden Sea. Dan. Rev. Game Biol. 16: 47-62.

Nielsen, T.G., Kiørboe, T., Bjørnsen, P.K. (1990): Effects of a Chrysochromulina polylepis subsurface bloom on the planktonic community. Ear. Ecol. Prog. Ser. 62: 21-35. 
S-E. GARBUS et al.: Incubation behaviour of Common Eiders Somateria mollissima in the Central Baltic: Nest attendance and loss in body mass

Öst, M., Ydenberg, R., Lindström, K., Kilpi, M. (2003): Body condition and the grouping behavior of brood-caring female common eiders (Somateria mollissima). Behav Ecol Sociobiol 54:451457.

Parker, H., Holm, H. (1990): Patterns of nutrient and energy expenditure in female Common Eider nesting in the high arctic. Auk. 107: 660-665.

R Core TeAm. (2015): R: A language and environment for statistical computing. R Foundation for Statistical Computing, Vienna, Austria. URL https://www.Rproject.org/.

Schmidt, L.E., Hansen, P.J. (2001): Allelopathy in the prymnesiophyte Chrysochromulina polylepis: effect of cell concentration, growth phase and $\mathrm{pH}$. Mar. Ecol. Prog. Ser. 216: 67-81.

Skov, H., Heinanen, S., Žydelis, R., Bellebaum, J., Bzoma, S., Dagys, M., Durinck, J., Garthe, S., Grishanov, G., Hario, M., Kieckbusch, J.J., Kube, J., Kuresoo, A., Larsson, K., Luigujoe, L., Meissner, W., Nehls, H.W., Nilsson, L., Petersen, I.K., Roos, M.M., Pihl, S., Sonntag, N., Stock, A., Stipniece, A., Wahl, J. (2011): Waterbird populations and pressures in the Baltic Sea. TemaNord 2011: 550.

Swennen, C. (1976): Populatie-structure en voedsel van de Eidereend Somateria m. mollissima in de Nederlandse Waddenzee. Ardea 64: 311-371. (In Dutch)

Swennen, C., Ursem, J.C.H., Duiven, P. (1993): Determinate laying and egg attendance in common Eiders. Ornis Scand. 24: 48-52.

Underdahl, B., Skulberg, O.M., Dahl, E., Aune, T. (1989): Disastrous bloom of Chrysochromulina polylepsis (Prymnesiophycceae) in Norwegian coastal waters 1988 - mortality in marine biota. Ambio. 18: 265-270.

Wakeley, J. S., Mendall, H. L. (1976): Migrational homing and survival of adult female eiders nesting in Maine. J. Wildl. Manage. 40: 15-21.

Wilcox, F.H., Cloud, W.S. (1965): Alkaline phosphatase in the reproductive system of the hen. J Reprod Fertil. 10: 321-328.

Yerkes, T. (1998): The influence of female age, body mass, and ambient conditions on Redhead incubation constancy. Condor. 100: 62-68.

Prispelo / Arrived: 7. 12. 2018

Sprejeto / Accepted: 5. 3.2019 
Table S1. Information on body mass before each intermission for incubating female \#01.

\begin{tabular}{ccc}
\hline$\# \mathbf{0 1}$ & Time $($ CET $)$ & Body mass $(\mathrm{g})$ \\
\hline 1. & $14-04-201520: 50$ & 2248 \\
2. & $21-04-201521: 02$ & 2011 \\
3. & $23-04-201523: 52$ & 1940 \\
4. & $28-04-201520: 54$ & 1842 \\
5. & $02-05-201521: 14$ & 1726 \\
6. & $06-05-201521: 30$ & 1630 \\
7. & $09-05-201503: 12$ & 1555 \\
\hline
\end{tabular}

Table S2. Information on body mass before each intermission for incubating female \#02.

\begin{tabular}{ccc}
\hline$\# \mathbf{0 2}$ & Time $($ CET $)$ & Body mass $(\mathrm{g})$ \\
\hline 1. & $21-04-201523: 29$ & 1883 \\
2. & $22-04-201521: 30$ & 1881 \\
3. & $24-04-201521: 21$ & 1742 \\
4. & $26-04-201522: 28$ & 1701 \\
5. & $28-04-201522: 11$ & 1683 \\
6. & $30-04-201523: 49$ & 1567 \\
7. & $02-05-201522: 23$ & 1562 \\
8. & $06-05-201517: 15$ & 1535 \\
9. & $07-05-201522: 04$ & 1360 \\
10. & $08-05-201521: 53$ & 1348 \\
11. & $09-05-201522: 18$ & 1367 \\
12. & $10-05-201522: 29$ & 1438 \\
13. & $11-05-201523: 42$ & 1416 \\
14. & $12-05-201522: 56$ & 1438 \\
15. & $13-05-201522: 35$ & 1356 \\
16. & $14-05-201523: 38$ & 1413 \\
17. & $15-05-201523: 31$ & 1355 \\
\hline
\end{tabular}

Table S3. Information on body mass before each intermission for incubating female \#03.

\begin{tabular}{lcc}
\hline$\# \mathbf{0 3}$ & Time $($ CET $)$ & Body mass $(\mathrm{g})$ \\
\hline 1. & $22-04-201520: 44$ & 1910 \\
2. & $24-04-201521: 38$ & 1861 \\
3. & $29-04-201523: 03$ & 1765 \\
4. & $01-05-201523: 18$ & 1732 \\
5. & $03-05-201502: 24$ & 1762 \\
6. & $06-05-201523: 39$ & 1672 \\
7. & $08-05-201522: 45$ & 1634 \\
8. & $10-05-201522: 48$ & 1605 \\
9. & $13-05-201500: 10$ & 1542 \\
10. & $14-05-201522: 45$ & 1522 \\
\hline
\end{tabular}

Table S4. Information on body mass of the incubating female \#04.

\begin{tabular}{lcc}
\hline$\# \mathbf{0 4}$ & Time $($ CET) & Body mass $(\mathrm{g})$ \\
\hline 1. & $22-04-201521: 08$ & 1761 \\
2. & $23-04-201521: 20$ & 1677 \\
3. & $24-04-201523: 36$ & 1676 \\
4. & $26-04-201523: 29$ & 1518 \\
5. & $29-04-201501: 58$ & 1472 \\
6. & $01-05-201500: 22$ & 1453 \\
7. & $03-05-201521: 29$ & 1350 \\
8. & $06-05-201517: 55$ & 1329 \\
9. & $08-05-201501: 35$ & 1280 \\
10. & $09-05-201522: 40$ & 1190 \\
11. & $11-05-201521: 31$ & 1284 \\
12. & $13-05-201522: 23$ & 1262 \\
13. & $14-05-201522: 55$ & 1232 \\
14. & $15-05-201521: 55$ & 1190 \\
15. & $17-05-201513: 18$ & 1120 \\
16. & $18-05-201521: 03$ & 1105 \\
\hline
\end{tabular}




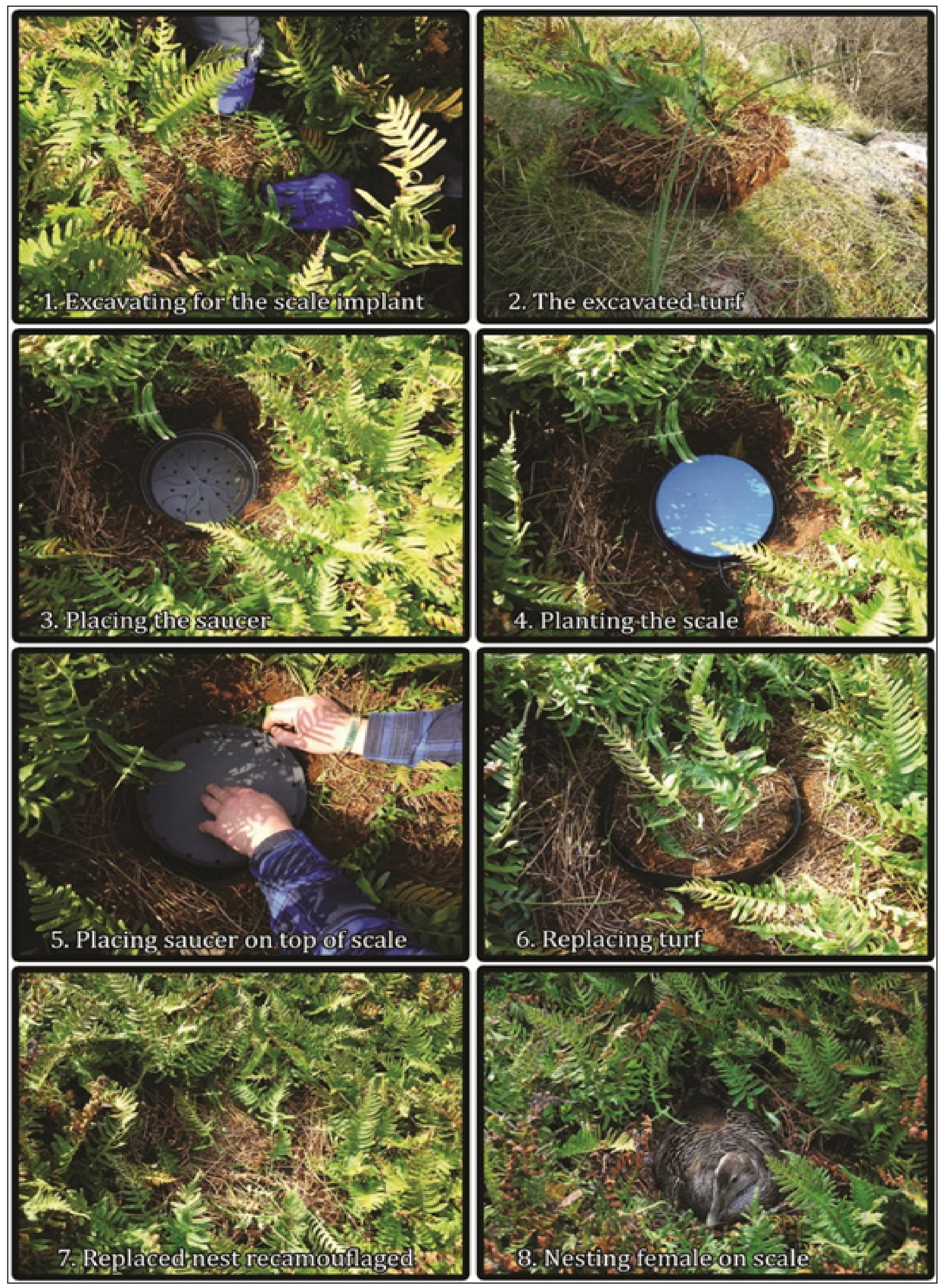

Figure S1. The implant of the automatic poultry scale systems. The scales were implanted in the pre-incubation period. 

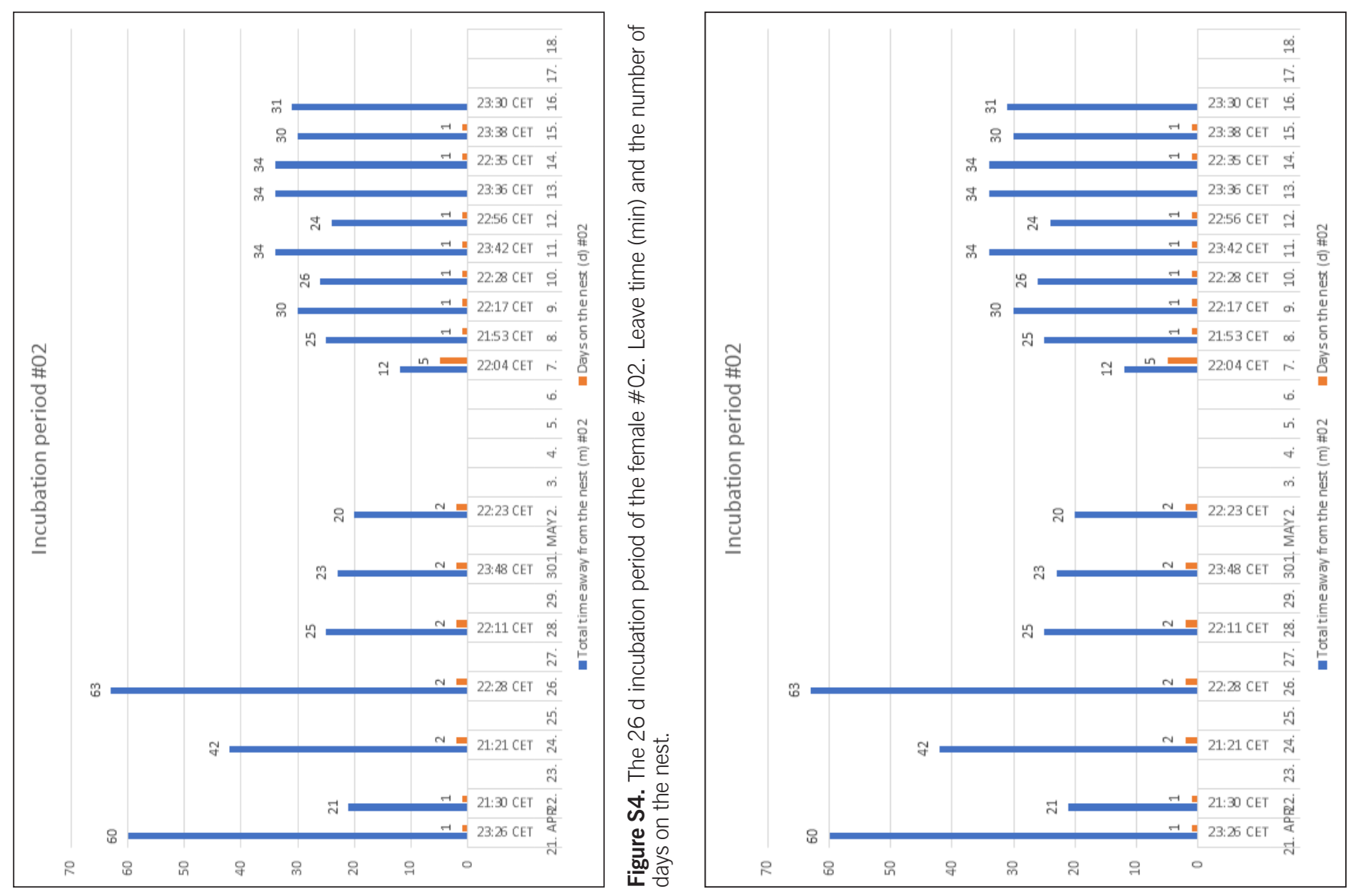

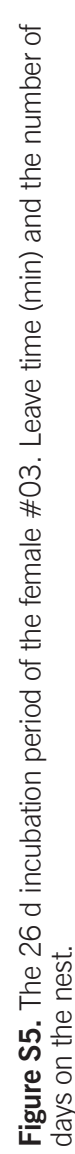
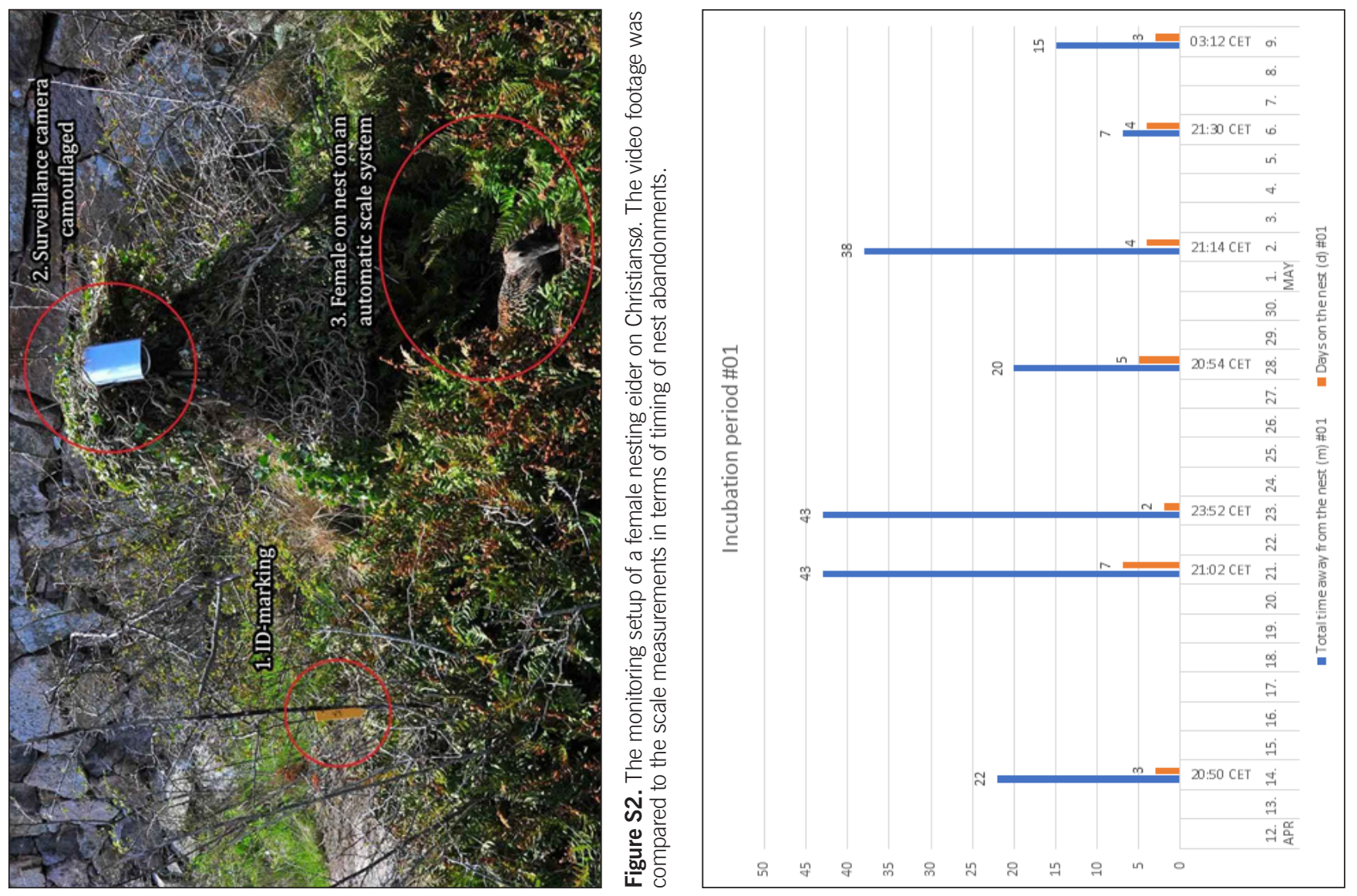

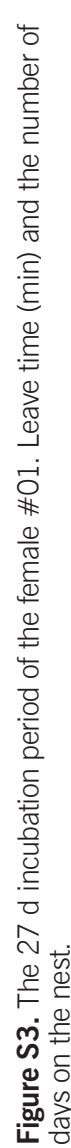




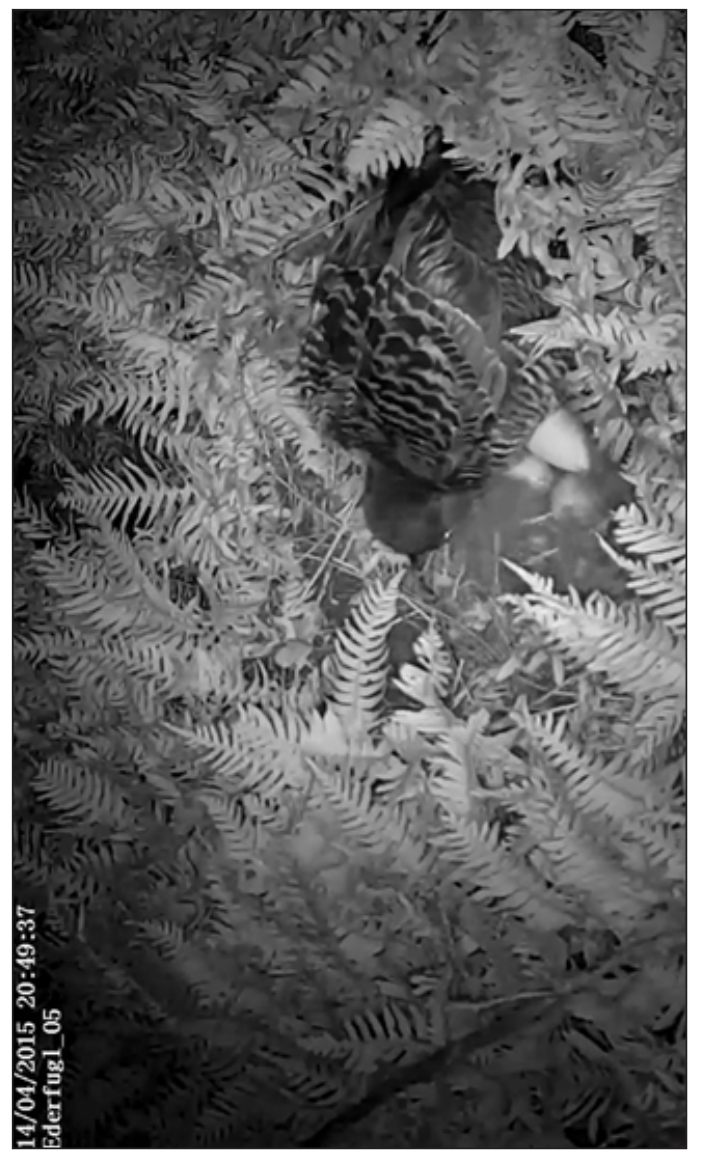

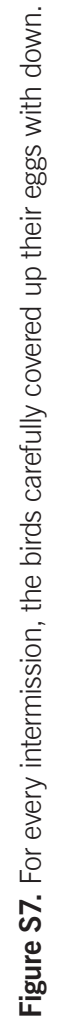

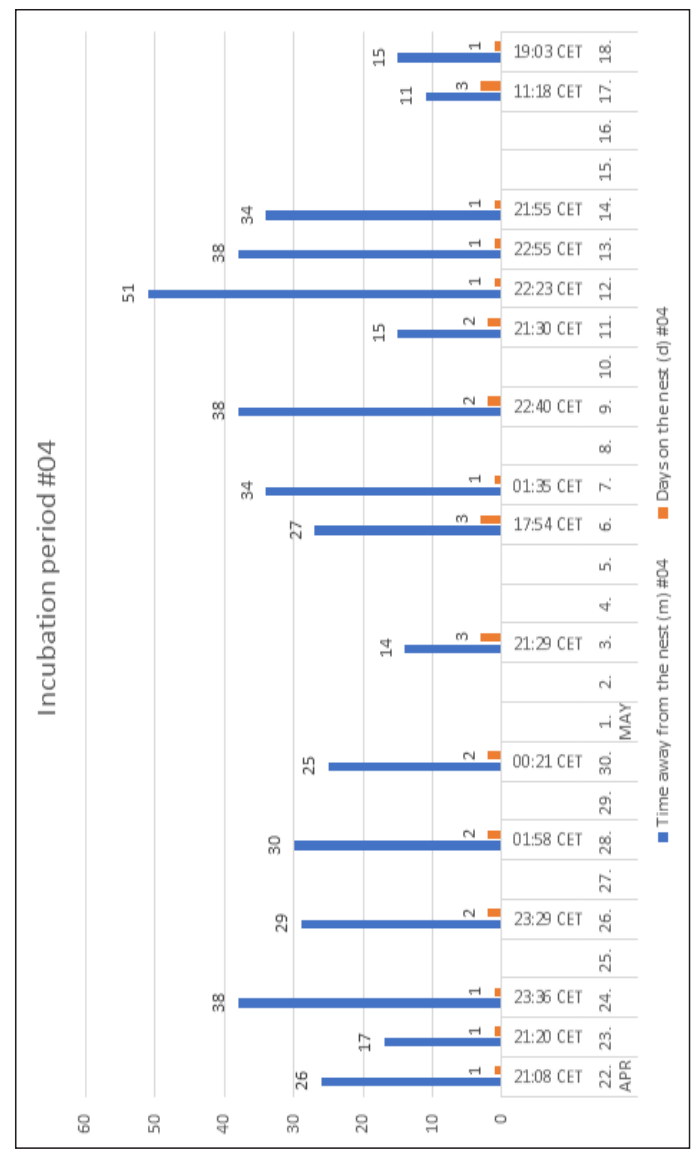

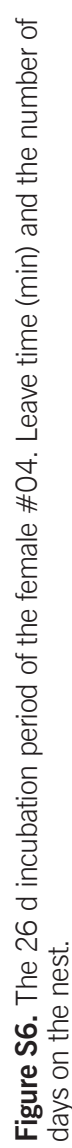




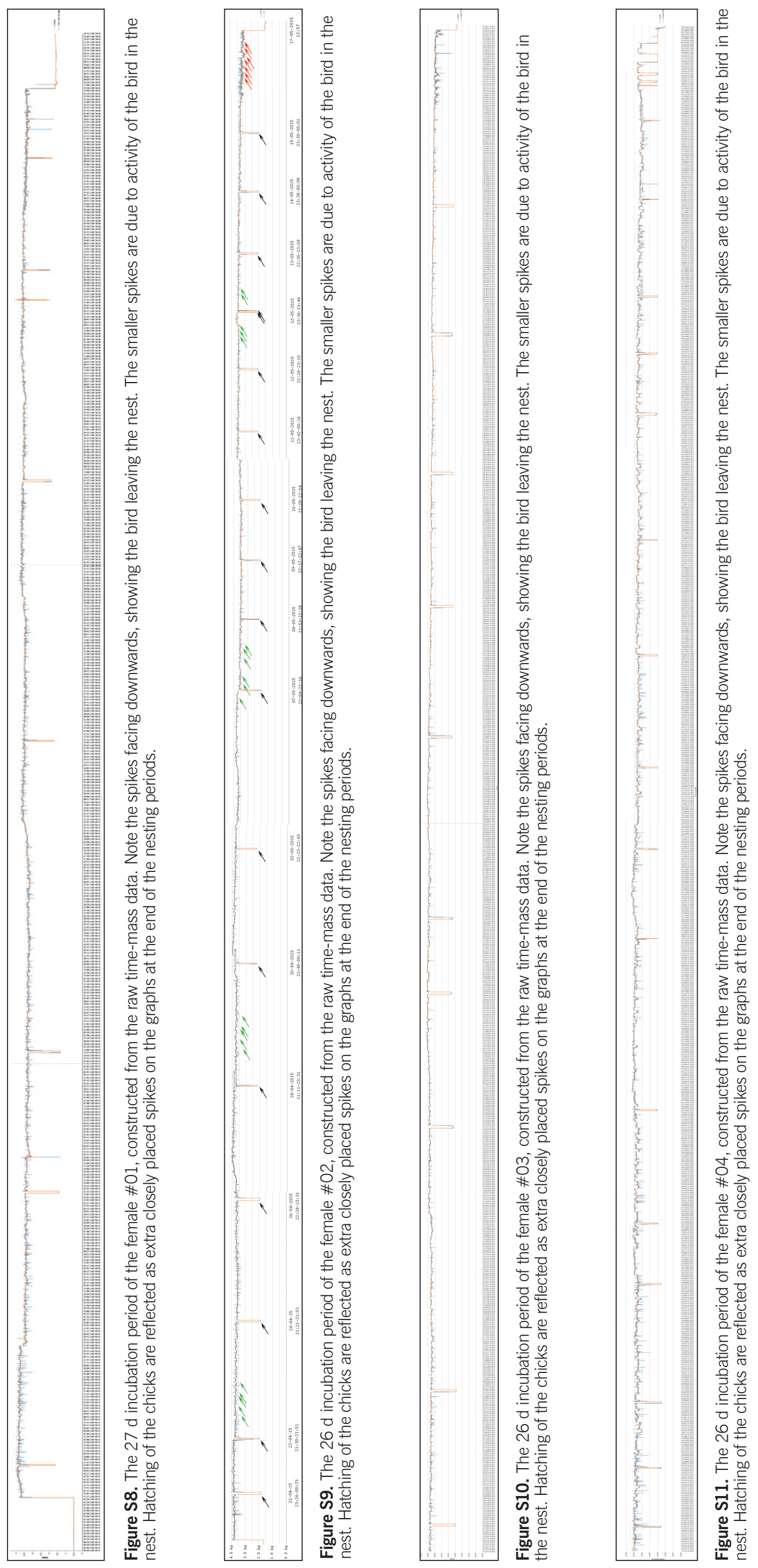




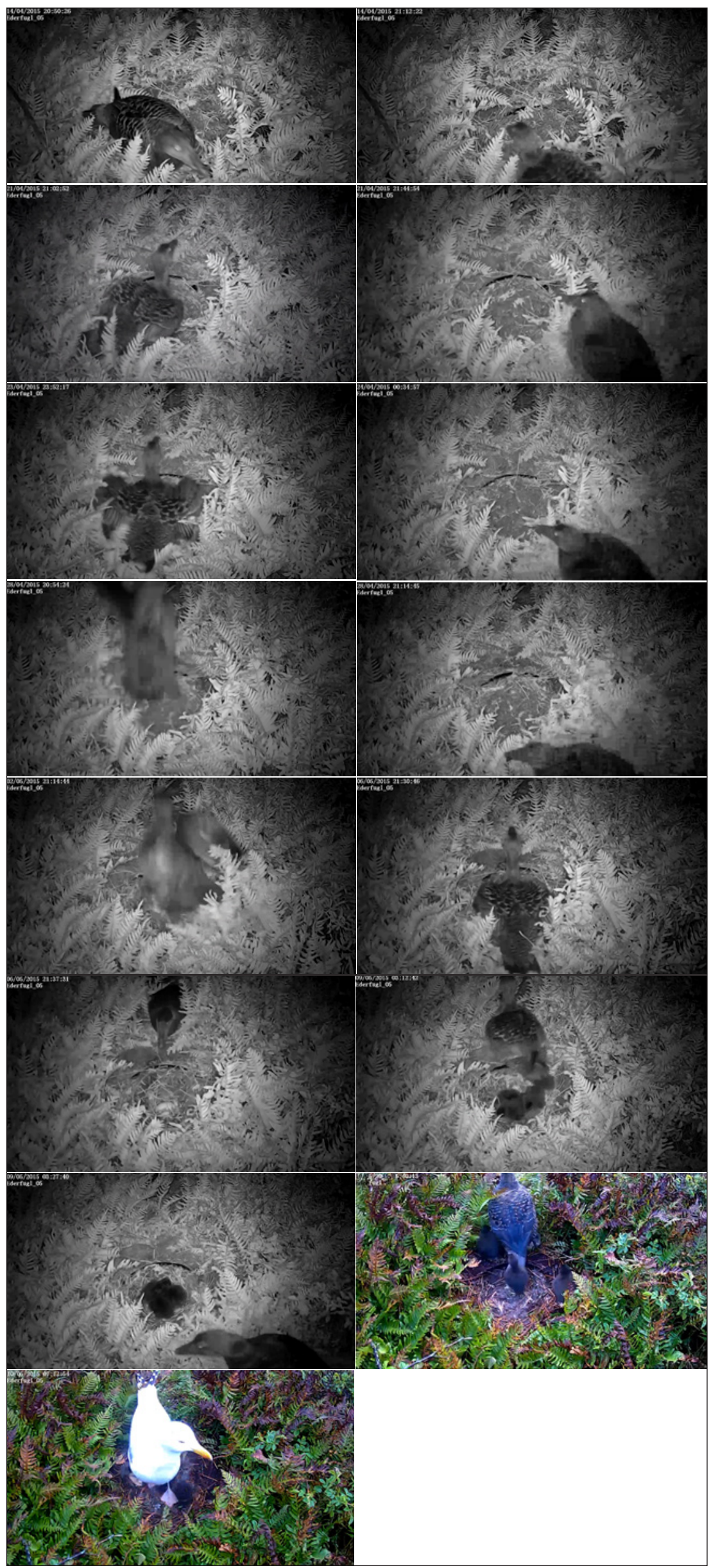

Figure S12. Still pictures of the female \#01 leaving and returning to the nest were captured and compared to the incubation intermissions shown on graph \#01 (Figure S3, S8). 